\title{
Life history traits of parental care in Crenicichla lepidota (Cichliformes, Geophagini) in the upper Paraguay River basin, Brazil
}

\author{
Matthijs Strietman ${ }^{1,3}$; Douglas Alves Lopes ${ }^{2,4}$; Thais Buzetti Barboza ${ }^{1,5}$ \& Fernando Rogério de Carvalho ${ }^{1,2,6}$ \\ ${ }^{1}$ Universidade Federal de Mato Grosso do Sul (UFMS), Instituto de Biociências (INBI0), Programa de Pós-Graduação em Biologia Animal (PPGBA). \\ Campo Grande, MS, Brasil. \\ 2 Universidade Estadual Paulista "Júlio de Mesquita Filho" (UNESP), Instituto de Biociências, Letras e Ciências Exatas (IBILCE), \\ Departamento de Zoologia e Botânica, Laboratório de Ictiologia, Programa de Pós-Graduação em Biologia Animal. São José do Rio Preto, SP, Brasil. \\ 3 ORCID: http://orcid.org/0000-0001-6014-6907. E-mail: taistrietman@gmail.com \\ ${ }^{4}$ ORCID: http://orcid.org/0000-0002-5607-3861.E-mail:douglas_alveslopes@hotmail.com \\ ${ }^{5}$ ORCID: http://orcid.org/0000-0001-8094-1959. E-mail: thaisbuzetti_Ip@hotmail.com \\ ${ }^{6}$ ORCID: http://orcid.org/0000-0002-2137-2255. E-mail: carvalhofr@gmail.com
}

\begin{abstract}
During focal observations carried out in the Olho d'Água River, upper Paraguay River basin, Brazil, we registered the defensive behaviour of one pair of Crenicichla lepidota attempting to protect their offspring from conspecific and non-specific predators. Adults exhibited substrate-guarding behaviour and displayed primary and secondary anti-predation mechanisms. The primary mechanisms (e.g., fin flicking and flaring, gill extending) were ineffective against conspecific predators or against other species. Secondary mechanisms included charging would-be predators of the offspring, and this tactic was successful against non-specifics. This record confirms, in the wild, agonistic behaviour as an effective secondary defence mechanism used in parental care in Crenicichla lepidota.
\end{abstract}

Key-Words. Defence of offspring; Substrate guarding; Neotropical cichlids; Anti-predation defence.

\section{INTRODUCTION}

Cichlidae is a diverse and species-rich family of fish, with more than 1,700 species and wide distribution across the Neotropics, Africa, and Asia (Chakrabarty, 2004; Fricke et al., 2020). They are known for their extensive repertoire of distinct parental care behaviours, including both 'substrate guarding' and mouthbrooding behaviours. While substrate guarding is thought to be an ancestral behaviour, mouth brooding is believed to have evolved independently several times within the cichlid lineage (Goodwin et al., 1998). These two main parental care modes are found among species exhibiting biparental or uniparental strategies (Wisenden \& Keenleyside, 1995; Goodwin et al., 1998). The use of uniparental or biparental strategies can vary between species of the same lineage and even within the same species, depending on environmental conditions (Gross, 2005; Kidd et al., 2012).

Within Neotropical cichlids, the genus Crenicichla Heckel, 1840 is the second most diverse, with almost 100 valid species (Lucena, 2007; Kullander \& Varella, 2015; Burress et al., 2017).
Crenicichla species are divided into five groups (based on morphological similarities and geographic distribution, sensu Piálek et al., 2012): C. lacustris group, C. lugubris group, C. wallacii group, C. saxatilis group, and C. reticulata group. However, recent phylogenetic data on Crenicichla shows that the genus is paraphyletic when not including Teleocichla, and the latter is likely a sixth group of species within Crenicichla (Burress et al., 2017). Species of the genus are found across cis-Andean Latin America in diverse habitats, ranging from the northern Amazon, east to Guyana and south across Brazil, and Argentina (Piálek et al., 2012; Burress et al., 2017). Crenicichla, as well as most Neotropical genus belonging to Cichlidae, are believed to display substrate guarding behaviour, although this information is estimated using evidence from only a few species (Goodwin et al., 1998). Much of the life cycle of Crenicichla species is known from aquarium observations or punctual studies of natural history, of which many are yet to be published, and with few scientific studies regarding their diet, reproduction and parental care in nature (Gurgel et al., 1998; Montaña \& Winemiller, 2009; Araújo et al., 2012). 
Crenicichla lepidota Heckel, 1840 is a species classified in Crenicichla saxatilis group (sensu Piálek et al., 2012), with wide distribution in the South America, occurring in Amazon and La Plata river basins (Kullander, 2003). The species was previously used as model in behaviour studies that approached the influences of tourism on the species in the regions of Baía Bonita and Nobres, both in the upper Paraguay River basin, Brazil (Sabino \& Andrade, 2003; Bessa \& Gonçalves-de-Freitas, 2014). These studies observed that $C$. lepidota is a territorial species, which attacks invaders (Bessa \& Gonçalves-de-Freitas, 2014) and exhibit parental care (Sabino \& Andrade, 2003). However, the energy investment in these behaviours can be negatively affected, due to human visitation (Sabino \& Andrade, 2003; Bessa \& Gonçalves-de-Freitas, 2014). In this study, we describe behaviours of Crenicichla lepidota defending offspring against potential predators in the wild.

\section{MATERIAL AND METHODS}

The offspring defence behaviour displayed by C. lepidota was recorded in a camera Go Pro 3 Plus, during observations made on July 2018 in the Olho d'Água River, Latitude: -21.436876, Longitude: -56.436000, in Jardim municipality, Mato Grosso do Sul State, Brazil. Initially, we used ad libitum observations in search of behavioural patterns of C. lepidota (Altmann, 1974). When identifying a couple of $C$. lepidota guarding the offspring, we used the focal-animal method (sensu Wooton, 1972) for 30 minutes to record the parental care behaviour. Visibility underwater was at least $10 \mathrm{~m}$ in the horizontal and observations were made at a depth of $1 \mathrm{~m}$, where the river is $20 \mathrm{~m}$ wide, near to the left margin, in an area of substrate covered by filamentous algae, starting at $2 \mathrm{pm}$. The observations were authorised by IBAMA (SISBIO 62795-1).

\section{RESULTS}

While snorkelling in the margins of the river, a pair of Crenicichla lepidota were observed shepherding a group of offspring over an algae bed (Fig. 1A). As the offspring were feeding among the algae, they were attacked by two conspecific adults (four attempts of attack, which resulted in two struck against the offspring) and different species (ten attempts of attack, all of them repelled by the parents) within a timeframe of thirty minutes. The parents instantly exhibited lateral threat-display, displaying the "flickering of fins" (Fig. 1B) thirteen times in an attempt to ward off predators. This was successful in some cases, but in one of the instances that this strategy was applied against another Crenicichla lepidota individual, the aggressor continued the attacks (Fig. 1C). It was able to strike the offspring twice (Fig. 1D) and was

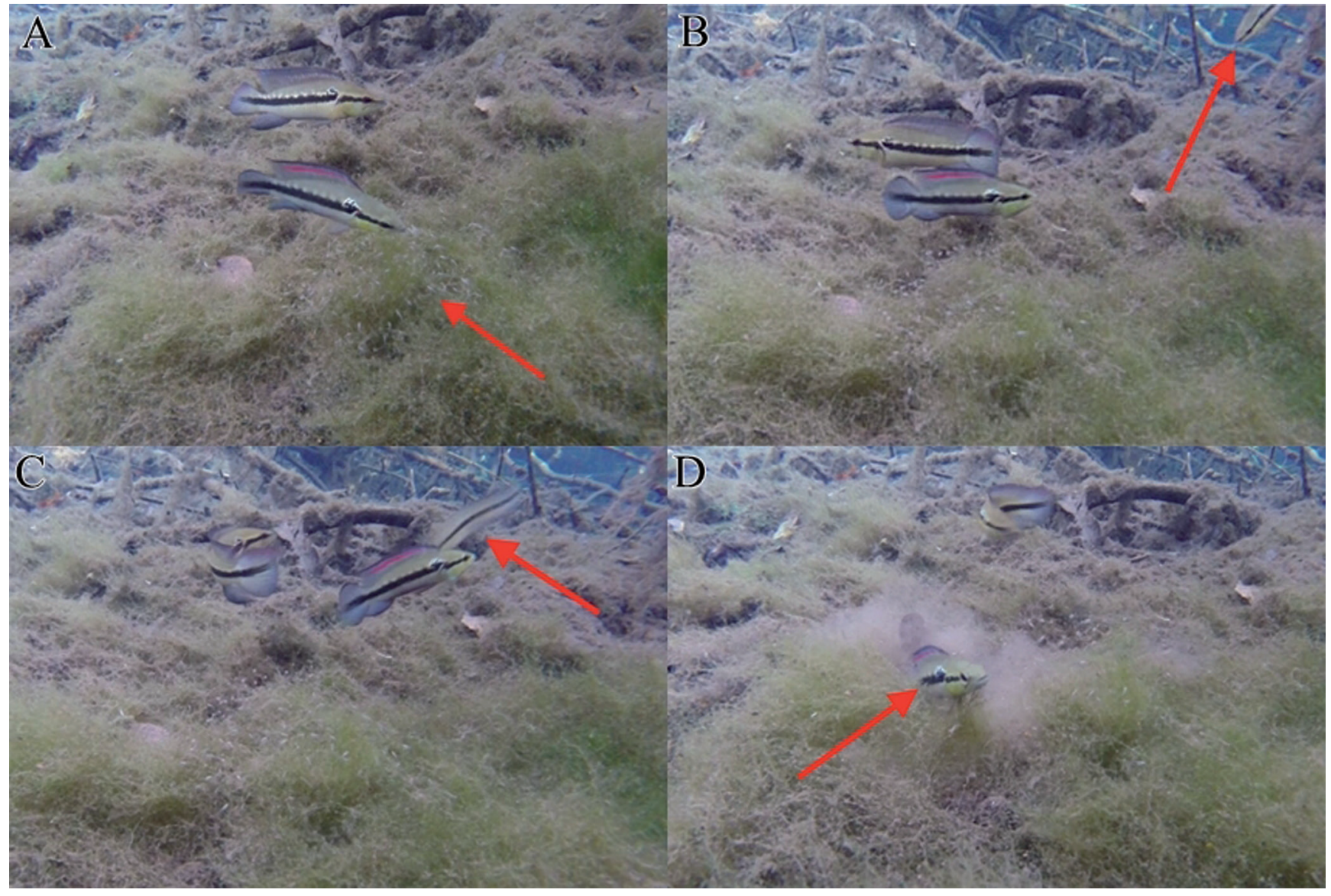

Figure 1. A couple of Crenicichla lepidota defence your offspring of a conspecific predator. (A) Pair of Crenicichla lepidota with offspring (indicated by arrow) over algae bed. (B) Conspecific aggressor (indicated by arrow) approaches, parents exhibit threat display. (C) Aggressor makes strike, parents continue threat display. (D) Aggressor strikes and is concealed in algae bed. Female (indicated by arrow) moves to prevent attack but fails. 
only repelled by secondary mechanisms of defence such as attacks and persecutions by the parents. However, a second $C$. lepidota specimen that also attempted to approach the offspring and was warded off only by threat-displays and flickering of fins from the parents. The other three species attacking the offspring were Serrasalmus maculatus Kner, 1858 (three attack attempts) (Fig. 2A), Hyphessobrycon eques (Steindachner, 1882) (six attack attempts) (Fig. 2B, C), and Cichlasoma dimerus (Heckel, 1840) (one attack attempt) (Fig. 2D). The parents, both male and female, were able to prevent attacks from these species by using defensive lateral-displays and by rushing the attackers head-on (a video with part of the recorded behaviour is made available as supplementary material).

\section{DISCUSSION}

Our observations agree with Goodwin et al. (1998), who infers that Crenicichla only uses biparental substrate-guarding (rather than mouthbrooding). Agonistic strategies for defending offspring among Crenicichla within the context of the species' abiotic and biotic environment can provide information on survival and predation rate, while also capturing the strategies and behaviours of syntopic species, showing synergistic interaction among species in wild. Although not observed in situations of parental care, agonistic interactions for the defence of territory are known among individuals of C. lepidota in other environments (Bessa \& Gonçalves-deFreitas, 2014) and also for other related species, such as Crenicichla brasiliensis (Bloch, 1792) and Teleocichla preta Varella, Kullander, Zuanon \& López-Fernández, 2016
(Araújo et al., 2014; Varella et al., 2016). It is likely that these and other species of Crenicichla exhibit similar parental behaviour to $C$. lepidota.

Biparental and uniparental care in the form of mouthbrooding or substrate-guarding is known to a number of cichlids (Goodwin et al., 1998). Substrate-guarding is common to Neotopical cichlid lineages, such as various species of Geophagus (Heckel, 1840) and Bujurquina vittata (Heckel, 1840), which employ extensive bi-parental care to ensure the safety of offspring (Keenleyside \& Bietz, 1981). Additionally, African cichlids, such as tilapia, can have a very elaborate parental care repertoire, with most species employing paternal or biparental mouthbrooding (Klett \& Meyer, 2002).

Substrate-guarding is present in all major lineages of cichlids and is the ancestral parental care behaviour in the family, whereas mouthbrooding is a derivative behaviour which has evolved independently several times along the cichlid tree of life (Goodwin et al., 1998). However, some species of the same lineage, such as Gymnogeophagus Miranda Ribeiro, 1918 and Satanoperca Günther, 1862, can exhibit both behaviours of substrate-guarding and mouthbrooding (Goodwin et al., 1998; Winberger et al., 1998). The form of uniparental or biparental care can also vary within the same lineage, with some populations of the same species exhibiting both forms, depending on mating opportunities, which influences this behaviour mainly in males (Gross, 2005). Keenleyside (1983) observed that Herotilapia multispinosa (Günther, 1867) males considerably increase their desertion rates as the proportion of females also increases in their environment, thus presenting populations with mostly bi-parental care and others with mostly maternal care. Variations in uniparental or biparental care have also been recog-

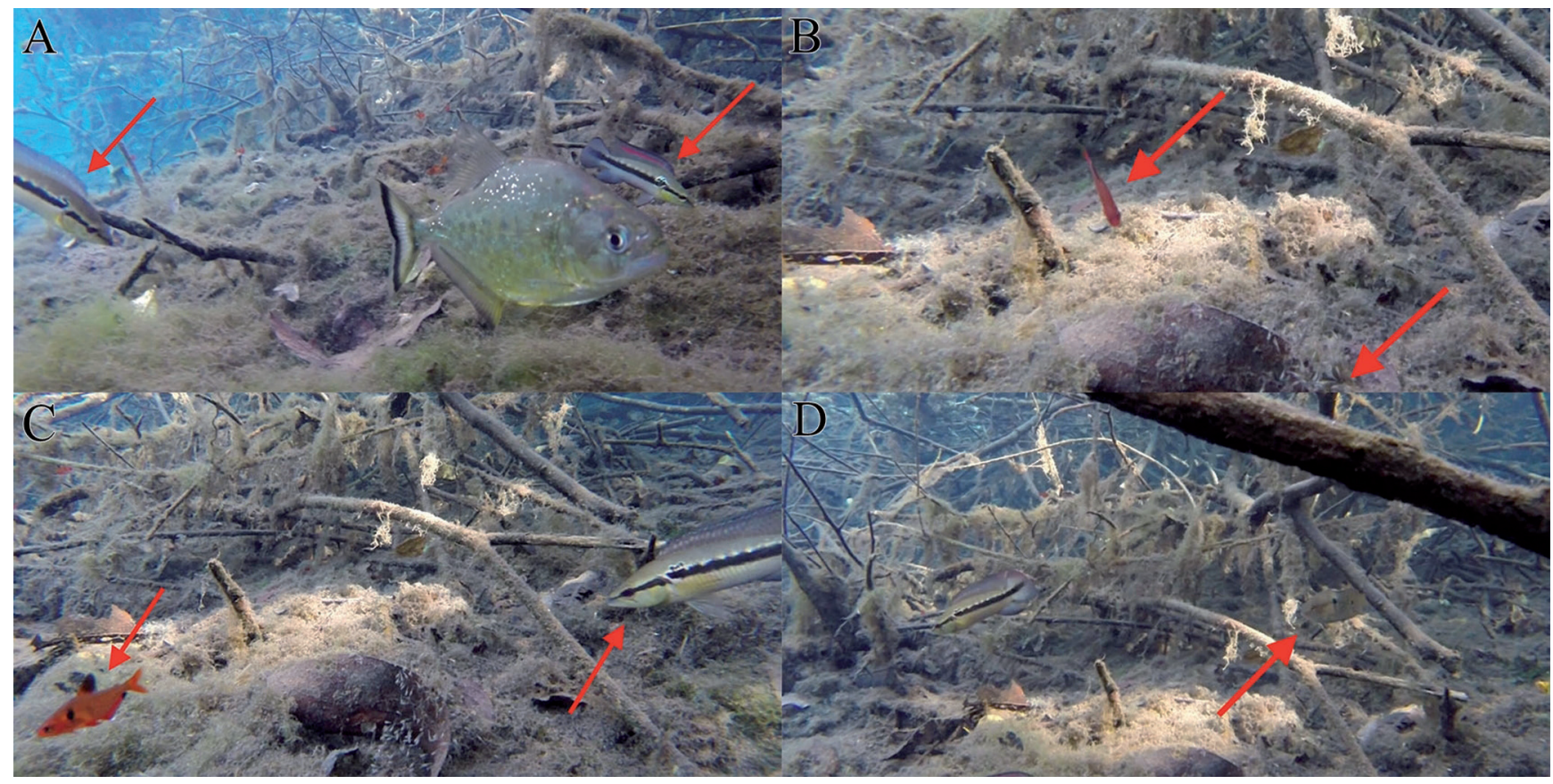

Figure 2. A couple of Crenicichla lepidota defence your offspring of a non-specific predators. (A) Both Crenicichla lepidota exhibit lateral threat display towards Serrasalmus maculatus; (B) Hyphessobrycon eques (indicated by arrow) approaches offspring(indicated by arrow bottom right) while parents are warding off another Crenicichla lepidota out of shot. (C) Male Crenicichla lepidota (indicated by arrow right) notices threat and charges Hyphessobrycon eques (indicated by arrow left). (D) Cichlasoma dimerus approaches offspring and adult of Crenicichla lepidota. 
nized for syntopic species of Xenotilapia Boulenger, 1899 of the Lake Tanganyika (Kidd et al., 2012).

Anti-predation defence mechanisms are classified by Edmunds (1974) as 'primary' and 'secondary', where primary mechanisms are used as measures to decrease the chance of confrontation and secondary to increase the chance of prey survival after a predator attack. These mechanisms are important in the structure and function of the fish community, directly influencing the dynamics and distribution of predator and prey populations (Hunghes, 1980). For example, one such primary mechanism, camouflage, is used by many species, including C. dandara and Teleocichla preta (Varella et al., 2016; Varella \& Ito, 2018) and although the application of this mechanism has not been tested in these cases, camouflage is used by many fish species to avoid predation (Machado, 1983; Sazima \& Machado, 1990). In this study, a pair of Crenicichla lepidota used the primary mechanisms of 'flicking' of fins, to indicate to a predator that they were aware of their presence, which may be intended to force the predator to give up from their attack (for fear of injury or reduced success) (Lowe-McConnell, 1987). The parents of C. lepidota were also observed using the secondary defence mechanism of charging would-be predators (Fig. 2A, C).

During conflicts over territory, Crenicichla males exhibit agonistic behaviour towards their opponents, including extended gills and flickering finnage (Araújo et al., 2014; Bessa \& Gonçalves-de-Freitas, 2014). This behaviour, also found in other fishes, as interpreted as a tentative of making themselves appear larger than they are (Telerph, 2004). Herein, both parents displayed in similar manner to other C. lepidota, to Cichlasoma dimerus and to Serrasalmus maculatus as a form of 'threat display'. However, in this case, an attacking C. lepidota continued its cannibalistic strike on the offspring of the conspecific pair after slowly moving towards them from several metres away. Indeed, C. lepidota is described as a stealthy predator which observes its prey before attacking (Keenleyside, 1979) and the careful approach (before the brazen attack) was confirmed herein. Furthermore, it is interesting that the defence mechanisms of the parent Crenicichla lepidota were not completely effective against conspecifics, but effective against other species, according to our observations.

Therefore, the parents of Crenicichla lepidota use primary (lateral displays and flickering of fins) to discourage potential predators of your offspring. When these mechanisms are not sufficient to prevent the attacks, both parents use secondary mechanisms, like attacks and persecutions. Future studies can analyse this behaviours with a quantitative approach to reveal other patterns of the parental care in C. lepidota and other cichlids and quantify the efficiency of this behaviour.

\section{ACKNOWLEDGMENTS}

The authors thank the anonymous reviewers for their great contribution to the improvement of the manuscript. This study was financed in part by the
Coordenação de Aperfeiçoamento de Pessoal de Nível Superior - Brazil (CAPES) - Finance Code 001 to MS, DAL and TBB. FRC is supported by the Fundação de Amparo à Pesquisa de Mato Grosso do Sul (FUNDECT, process \#59/300.093/2017) and Conselho Nacional de Desenvolvimento Cientifico e Tecnológico (CNPq, process \#420620/2018-4). We wish to thank the Recanto Ecológico Rio da Prata for supporting this study.

\section{AUTHORS' CONTRIBUTIONS}

MS: wrote the manuscript and main consultant of bibliography. DAL: assisted in writing manuscript, did the revisions and ensured standardization and following of journal norms. TBB: recorded images and assisted with writing manuscript. FRC: assisted with writing manuscript, mainly the discussion and is the supervisor of above the three contributors.

\section{REFERENCES}

Altmann, J. 1974. Observational study of behaviour: sampling methods. Behaviour, 49(3): 227-267.

Araújo, A.S.; do Nascimento,W.S.; Yamamoto,M.E.\&Chellappa,S. 2012. Temporal dynamics of reproduction of the neotropical fish, Crenicichla menezesi (Perciformes: Cichlidae). The Scientific World Journal, 2012(579051): 1-11.

Araújo, A.S.; Oliveira, J.C.S.; Barros, N.H.C.; Yamamoto, M.E. \& Chellappa, S. 2014. Dinâmica do comportamento territorial de Crenicichla menezesi (Osteichthyes: Perciformes: Cichlidae). Biota Amazonia, 4(1): 37-44.

Bessa, E. \& Gonçalves-de-Freitas. 2014. How does tourist monitoring alter fish behaviour in underwater trails? Tourism management, 45: 253-259. DOI

Burress, E.D.; Alda, F.; Duarte, A.; Loureiro, M.; Armbruster, J.W. \& Chakrabarty, P. 2017. Phylogenomic of pike cichlids (Cichlidae: Crenicichla): the rapid ecological speciation of an incipient species flock. Journal of Evolutionary Biology, 31(1): 14-30.

Chakrabarty, P. 2004. Cichlid Biogeography: comment and review. Fish and Fisheries, 5: 97-119. DOI

Edmunds, M. 1974. Defence in animals: a survey of anti-predator defences. Harlow, Longman. 357p.

Fricke, R.; Eschmeyer, W. \& Fong, D. (Eds.). 2020. Catalog of Fishes: Genera, Species, REFERENCES. Available: http://researcharchive.calacademy.org/ research/ichthyology/catalog/fishcatmain.asp. Access: 12/02/2020.

Goodwin, N.B.; Balshine-Earn, S. \& Reynolds, J.D. 1998. Evolutionary transitions in parental care in cichlid fish. Proceedings of Real Society of London, 265(1412): 2265-2272. D0I

Gross, M.R. 2005. The evolution of parental care. The Quarterly Review of Biology, 80(1): 37-45.

Gurgel, H.C.B.; Almeida, R.G.; Barbieri, G. \& Vieira, L.J.S. 1998. Dieta de Crenicichla lepidota Heckel, 1840 (Perciformes, Cichlidae) da Lagoa Redonda, Nísia Floresta/RN. Acta Scientiarum, 20(2): 191-194.

Hunghes, R.N. 1980. Predation and community structure. In: Irvine, D.E.G. \& Farnham, W.F. (Eds.). The shore environment. vol. 2, Ecosystems. London, Academic Press. p. 699-728. (Systematics Association Special Volume, 17).

Keenleyside, M.H.A. 1979. Diversity and adaptations in fish behaviour. Berlin, Springer-Verlag. 208p.

Keenleyside, M.H.A. 1983. Mate desertion in relation to adult sex ratio in the biparental cichild fish Herotilapia multispinosa. Animal Behaviour, 31(3): 683-688. 
Keenleyside, M.H.A. \& Bietz, B.F. 1981. The reproductive behaviour of Aequidens vittatus (Pisces, Cichlidae) in Surinam, South America. Environmental Biology of Fishes, 6(1): 87-94. D0I

Kidd, M.R.; Duftner, N.; Koblmüller, S.; Sturmbauer, C. \& Hofmann, H.A. 2012. Repeated parallel evolution of parental care strategies within Xenotilapia, a genus of Cichlidae fishes from Lake Tanganyika. Plos One, 7(2): 1-8. DOI

Klett, V. \& Meyer A. 2002. What, if anything, is a Tilapia? Mitochondrial ND2 phylogeny of Tilapiines and evolution of parental care systems in the African Cichlid fishes. Molecular Biology and Evolution, 19(6): 865-883. DOI

Kullander, S.0. 2003. Family Cichlidae. In: Reis R.E.; Kullander, S.0. \& Ferraris-Jr., C.J. Check list of the freshwater fishes of South and Central America. Porto Alegre, EDIPUCRS. p. 605-654.

Kullander, S.0. \& Varella, H.R. 2015. Wallace's Pike cichlid gets a nameafter 160 years: a new species of cichlid fish (Teleostei: (ichlidae) from the upper Rio Negro in Brazil. Copeia, 103(3): 512-519.

Lowe-McConnell, R.H. 1987. Ecological studies in tropical fish communities. Cambridge, Cambridge University Press. 382p.

Lucena, C.A.S. 2007. Two new species of the genus Crenicichla Heckel, 1840 from the Uruguay drainage (Perciformes: Cichlidae). Neotropical Ichthyology, 5(4): 449-456.

Machado, F.A. 1983. Comportamento e hábitos alimentares de quarto espécies de Cichlidae (Teleostei) no Pantanal Matogrossense. Campinas, SP, Universidade Estadual de Campinas. (Dissertação-Mestrado). 80p.

Montaña, C.G. \& Winemiller, K.0. 2009. Comparative feeding ecology and habitats use of Crenicichla species (Perciformes: Cichlidae) in a Venezuela floodplain river. Neotropical Ichthyology, 7(2): 267-274. DOI
Piálek, L.; Rícan, 0.; Casciotta, J.; Almirón, A. \& Zrzavy, J. 2012. Multilocus phylogeny of Crenicichla (Teleostei: (ichlidae), with biogeography of the C. lacustris group: species flocks as a model for sympatric speciation in rivers. Molecular Phylogenetics and Evolution, 6(2): 46-61.

Sabino, J. \& Andrade, L.P. 2003. Uso e conservação da ictiofauna no ecoturismo da região de Bonito, Mato Grosso do Sul: 0 mito da sustentabilidade ecológico no rio Baía Bonita (Aquário Natural de Bonito). Biota Neotropical, 3(2): 1-6. D0I

Sazima, I. \& Machado, F.A. 1990. Underwater observations of piranhas in western Brazil. Enviromental Biology of Fish, 28: 17-31.

Telerph, T.A. 2004. The function of agonistic display behaviours in Gnathonemus petersii. Animal Behaviour, 64: 7-1373.

Varella, H.R. \& Ito, P.M.M. 2018. Crenicichla dandara, new species: the black jacundá from the rio Xingu (Teleostei: (ichlidae). Proceedings of the Academy of Natural Sciences of Philadelphia, 166: 1-13.

Varella, H.R.; Zuanon, J.; Kullander, S.0.; López-Fernández, H. 2016. Teleocichla preta, a new species of cichlid from the Rio Xingu Basin in Brazil (Teleostei: Cichlidae). Journal of Fish Biology, 89(3): 1551-1569.

Winberger, P.H.; Reis, R.E. \& Thornton, K.R. 1998. Mitochondrial phylogenetics, biogeography, and evolution of parental care and matyng systems in Gymnogeophagus (Perciformes, Cichlidae), 509-518. In: Malabarba, L.R.; Reis, R.E.; Vari, R.P.; Lucena, Z.M. \& Lucena, C.A. (Eds.). Phylogeny and classification of Neotropical fishes. Porto Alegre, Edipucrs. 603p.

Wisenden, B.D. \& Keenleyside, M.H.A. 1995. Brood size and the economy of brood defence: examining Lack's hypothesis in a bi-parental cichlid fish. Environmental Biology of fishes, 43: 145-151.

Wooton, R.J. 1972. The behaviour of the male three-spined stickleback in a natural situation: A quantitative description. Behaviour, 4: 232-241.

\section{SUPPORTING INFORMATION}

Video: A sequence of behaviours of parental care of a pair of Crenicichla lepidota, defending your offspring of conspecific and non-specific predators (click on the image below to see the video).

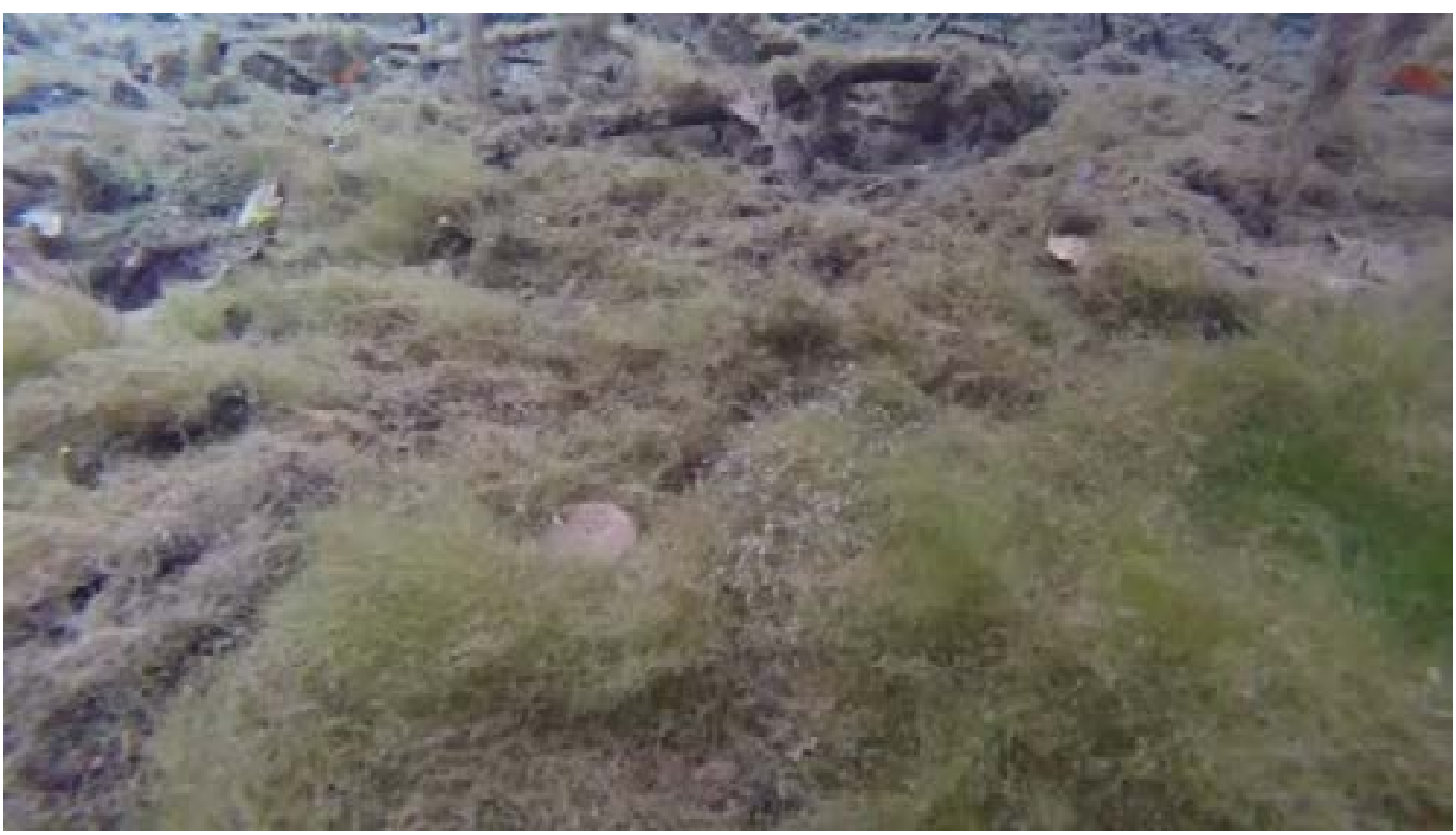

